\title{
When Do 'Female' Occupations Pay More?
}

\author{
Štěpán Jurajda and Heike Harmgart \\ CERGE-EI University College London
}

December 28, 2005

\begin{abstract}
Highly 'female' occupations typically offer low pay. Occupational gender segregation is therefore a leading explanation for the gender wage gap. Yet, its effects are not fully understood. In this paper, we use a 1995 sample of social-security wage records of full-time German workers to show that in East Germany predominantly 'female' occupations actually pay more to both men and women and that there is no relationship between occupation-specific concentration of women and wages in West Germany. Relying on workers who change occupations to fully condition on labor quality, we find a negligible wage impact of segregation. These findings are consistent with the imposition of high wage levels in East Germany at the outset of reforms and the selection of mainly high-skill women into employment. Linking our results with the U.S. and post-communist evidence suggests an important role of the participation of low-skill women in employment for the observed wage 'penalty' to 'female' occupations.
\end{abstract}

JEL classification: J31, J71, P20

Acknowledgements Jurajda is also affiliated with CEPR, IZA, and WDI. The authors would like to thank Michael Burda, Randall Filer, Andrea Ichino, Dean Jolliffe, Joep Konings, and Rudolf Winter-Ebmer for helpful comments. Harmgart would like to thank the Institute for Economic Theory II at the Humboldt University Berlin for letting her use the IAB data. This research was supported by Volkswagen Stiftung through grant no. II/75 828. While revising this paper, Jurajda was also supported by the CERGE-EI World Bank Fellowship.

Address Jurajda: CERGE-EI, Politických vězňů 7, Prague, Czech Republic. E-mail: stepan.jurajda@cerge-ei.cz CERGE-EI is a joint workplace of the Center for Economic Research and Graduate Education, Charles University, and the Economics Institute of the Academy of Sciences of the Czech Republic. Harmgart: The Institute of Fiscal Studies, 7 Ridgemount Street, London, WC1E7AE. 


\title{
When Do 'Female' Occupations Pay More?
}

\begin{abstract}
Highly 'female' occupations typically offer low pay. Occupational gender segregation is therefore a leading explanation for the gender wage gap. Yet, its effects are not fully understood. In this paper, we use a 1995 sample of social-security wage records of full-time German workers to show that in East Germany predominantly 'female' occupations actually pay more to both men and women and that there is no relationship between occupation-specific concentration of women and wages in West Germany. Relying on workers who change occupations to fully condition on labor quality, we find a negligible wage impact of segregation. These findings are consistent with the imposition of high wage levels in East Germany at the outset of reforms and the selection of mainly high-skill women into employment. Linking our results with the U.S. and post-communist evidence suggests an important role of the participation of low-skill women in employment for the observed wage 'penalty' to 'female' occupations.
\end{abstract}

\section{Introduction}

One of the most clearly established facts in the U.S. literature on the gender wage gap is that there are large and persistent differences in the share of female workers across occupations and that wages of both men and women decrease with the presence of females in their occupation. Such evidence has been recently offered even outside of the most developed countries - in several post-communist economies. ${ }^{1}$ Concentration of women in low paying occupations is therefore a major source of the gender wage gap. Yet, its effects are not fully understood.

There are three main possible explanations for why 'female' occupations pay less. First, women may face discriminatory hiring, firing, and promotion practices, which prevent them from working in high-wage occupations. Second, 'female' occupations may offer costly non-wage characteristics (e.g., flexibility of work hours); women are then more likely to accept lower wages because they prefer such occupational attributes. Third, workers employed in 'female' occupations may on average have lower skills (both observed and/or unobserved).

Researchers measuring the relationship between individual wages and the 'femaleness' of occupations have therefore recently taken into account not only observed productive characteristics of workers, but also occupational attributes and unmeasured worker skills and occupational prefer-

\footnotetext{
${ }^{1}$ See Ogloblin (1999) for evidence on Russia and Jurajda (2003) for results from the Czech and Slovak Republics.
} 
ences. In the U.S. and Canada, controlling for these additional factors substantially reduces the wage 'penalty' to female jobs (Macpherson and Hirsh, 1995; Baker and Fortin, 2001). Another line of research uses cross-country differences in labor-market institutions and wage structures to study the sources of the gender wage gap (Blau and Kahn, 2003) and the 'penalty' to working in predominantly female occupations (Baker and Fortin, 1999).

In this paper, we extend the literature by investigating the effect of occupational gender composition on wages in East and West Germany in 1995. We offer not only traditional cross-sectional estimates of the wage 'penalty' to highly 'female' occupations, but in a subset of our analysis, we also control for unobservable worker heterogeneity, including unmeasured skills.

Our results extend the set of available cross-country comparisons in a potentially useful way. We contrast our West German evidence with U.S. findings and compare the East German results to those from other transition economies. West Germany represents a regulated European labor market with a stable, compressed wage structure and low female employment rates. The comparison of East Germany to other post-communist countries is interesting because East Germany has been subject to the most radical pro-market reform among all transition economies as the German unification brought about instant implementation of western-style labor market institutions, high wage levels and a sharp decrease in employment rates. ${ }^{2}$ In contrast, in other countries, such as the Czech Republic, wages actually decreased in early transition and employment rates declined less dramatically. These different reform paths may have affected the relative wage and employment position of women differently. While the gender wage gap has been stable or growing in most postcommunist countries (Newell and Reilly, 2000; Brainerd, 2000), the East German gap has decreased since unification. Hunt (2002) suggests that this has been in large part due to low-earning women selectively dropping out of the labor force. However, no evidence exists on the extent and the wage effects of gender segregation in East Germany.

\footnotetext{
${ }^{2}$ Enterprise restructuring led to a 35 percent drop in employment between 1989 and 1992 (Burda and Hunt, 2001).
} 
In this paper, we therefore reduce the gap in the empirical literature by measuring occupational segregation and investigating its effects on the gender pay gap in both parts of Germany. Specifically, we employ a large representative administrative sample of workers from 1995- the so called IAB employment subsample, which consists of wage records drawn from the German Social Security (Unemployment Insurance) database. Due to a lack of information on hours worked we focus on full-time workers. In a subset of our analysis, we form a matched employer-employee data set, which enables the study of within-establishment wage differences. The wage structure is described using logarithmic wage regressions conditioning on worker and firm characteristics as well as on the fraction of women within a given occupation. We estimate the cross-sectional relationship between wages and segregation and we also attempt to come closer to a causal effect of segregation on wages by conditioning on unobservable worker skills and occupational preferences. To do so, we use a panel of workers employed in 1992 and 1995, the earliest and latest years for which the (East German) data are available, to remove all time-constant worker characteristics. The estimated coefficients are then used together with the mean differences in explanatory variables by gender to quantify the part of the wage gap explained by gender segregation.

Our analysis uncovers intriguing East-West differences. While the gender structure of occupations is similar in both parts of Germany, the gender pay gaps differ substantially. The West German wage gap is considerable, both across all workers and within jobs (occupation-firm cells), but there is almost no difference between the median wages of East German full-time male and female workers. Yet, there are significant East German gender wage gaps within jobs. Our regression analysis reconciles these pieces of descriptive evidence: We find little support for the existence of a wage 'penalty' to 'female' jobs in West Germany. The significant within-job wage gaps in East Germany do not appear at the aggregate level because more 'female' occupations actually offer higher wages, in striking contrast to findings from the U.S. as well as from transition countries. Yet, conditioning on unobservable worker heterogeneity (skills), the wage impact of gender segregation is small 
in both parts of Germany. We rely on indirect evidence, both within- and cross-country, to offer an explanation for this arresting set of findings. The explanation is related to the radical reform path of East Germany and motivates future cross-country research that may shed new light on the segregation/wage-gap literature.

\section{Background}

\subsection{Occupational Gender Segregation and Wage Gap}

Occupational segregation is the subject of extensive research. It is more pronounced in the EU countries compared to the U.S. for low-educated workers (Dolado et al., 2002). There is widespread evidence that wages of both male and female workers are lower when they are employed in predominantly female occupations; see Kilingsworth (1990), Groshen (1991) or Bayard et al. (2003) for U.S. evidence, and Baker and Fortin (2001) for results from Canada. While occupational segregation is often attributed to discriminatory employer practices, Filer (1986) and Macpherson and Hirsh (1995) are among the researchers who suggest that it is in large part due to gender differences in preferences for occupational characteristics or to sorting on unobserved skills.

The suggested mechanisms giving rise to the observed negative correlations between the female share of an occupation's workforce and the respective wages of men and women often differ by gender. For example, if women are discouraged from entering high-wage occupations by discriminatory barriers, then only women with very high (possibly unobservable) skills may be able to enter the typically 'male' occupations. The fraction of female workforce then may become an index of labor quality and only low-skill men may sort themselves into the more 'female' occupations. ${ }^{3}$

Another strand of the literature relies on cross-country research design to analyze the importance of labor market institutions for employment patterns by gender (Bertola, et. al, 2002), the gender wage gap (Blau and Kahn, 2003) or the occupational gender segregation (Baker and Fortin, 1999). Comparing the United States and Canada, Baker and Fortin (1999) find the wage 'penalty' to

\footnotetext{
${ }^{3}$ For a theoretical model where workers of complementary skills are grouped together see Kremer (1993).
} 
occupations mainly employing female workers to be larger in the U.S. and link this finding to a low U.S. female unionization rate and low wages in certain public-goods-sector jobs. However, there are no detailed studies comparing occupational segregation wage effects in the regulated European labor markets to those found in the Anglo-Saxon economies.

Among the West-German gender-wage-gap studies, Kunze (2003) focuses on occupational gender segregation. Specifically, she looks at the early careers of workers entering the West German labor market during 1975 to 1990 with apprenticeship degrees and shows that occupational gender segregation explains a large and persistent part of the gender pay gap for these workers.

\subsection{Female Wages in Transition}

There is a wealth of research analyzing the evolution of the gender wage gap during early promarket reforms when wage dispersion increased dramatically and when labor force participation rates decreased from the artificially high levels of the communist era. ${ }^{4}$ A typical finding from these studies is that gender differences in observed worker characteristics contribute little towards the significant raw wage gaps between men and women. While the gender wage gap has been quite stable in many transition countries (Newell and Reilly, 2000), it has dropped by about 10 percentage points in East Germany. Hunt (2002) attributes much of this decrease to low-earning women selectively dropping out of the labor force. ${ }^{5}$

The 1990 monetary union between East and West Germany led to a large increase in East German wage level while western trade unions took over the East German wage bargaining system. Drastic restructuring and mass layoffs were accompanied by early retirement policies and other public-assistance programs. Hunt argues that union wage rises have caused the less productive to be laid off and that the decreased child care availability in the eastern states was not important in the selective layoff process. In 1995, the year of our analysis, the East German female employment

\footnotetext{
${ }^{4}$ See, e.g., Brainerd (1998) for Russia or Jolliffe (2002) for Bulgaria. Ogloblin (1999) and Brainerd (2000) provide an analysis of the institutional background to gender under communism.

${ }^{5}$ Similar to Hunt (2002), Gang and Yun (2001) also use data from the German Socio-Economic Panel and report a declining, but nonzero, gender wage gap in East Germany during the early 1990s.
} 
ratio was comparable to that of West Germany. ${ }^{6}$

Out of the many gender wage gap studies of transition economies, only two pay close attention to the issue of gender segregation. Ogloblin (1999) analyzes the Russian Longitudinal Monitoring Survey from 1994-1996 and finds that the gender pay gap cannot be explained by gender differences in education and experience. However, additional conditioning on industry and firm ownership dummies as well as on a class of occupational dummies capturing overwhelmingly 'male' and 'female' occupations accounts for over 80 percent of the Russian wage gap. Jurajda (2003) uses large matched employer-employee data covering medium- and large-firm Czech and Slovak employment in 1998 to suggest that in Central Europe segregation of women into low-paying occupations and firms is responsible for only about one third of the total wage gap.

\section{Data}

The data we use consist of a one-percent random sample of the German Social Security (Unemployment Insurance) records, perhaps better known as the IAB employment subsample. ${ }^{7}$ The West German data is available from 1975 until 1995 while the East German file spans the 1992-1995 period. The original data consists of various types of social security records (notifications) including the start and end of employment spells. The employment (and wage) information is also updated at the end of each year. The 1995 end-of-year cross-section of employees forms the basis for our analysis. In a subset of our analysis, we also use the panel of workers employed in both 1992 and 1995.

German social security (unemployment insurance) reporting covers virtually all of its enterprise

\footnotetext{
${ }^{6}$ Using the 1995 Microcensus data, the female (male) employment ratio is 0.36 (0.53) in West Germany and 0.38 (0.51) in East Germany. The corresponding female (male) labor force participation rate is $0.39(0.58)$ in West Germany and 0.48 (0.57) in East Germany. The high level of female labor-force participation in East Germany has been explained by Bonin and Euwals (2002) as being largely due to the different pro-participation characteristics of the Eastern female workforce, inherited from the communist times of female labor-market emancipation.

${ }^{7}$ See Bender et al. (2000) for a detailed data description. The data are anonymized and distributed through the Institut für Arbeitsmarkt und Berufsforschung der Bundesanstalt für Arbeit (IAB), the German Institute for Employment Research.
} 
employment. Only civil servants and self-employed workers are not contributing to the unemployment insurance system (and are therefore excluded from the IAB sample). ${ }^{8}$ As of 1995 , the social security records cover almost 80 percent of total West German employment and over 86 percent of East German employment.

Besides a number of personal and firm characteristics, including the workers' occupation, the data also provide average gross daily wages for each corresponding employment notification. Having only daily wage rates, as opposed to hourly rates, is a major weakness of our study. It may lead us to confound gender differences in hours worked with true wage-rate differentiation; hence, we focus our analysis on full-time employment in order to minimize work time differences. ${ }^{9}$ While wages of part-timers remain outside the scope of our analysis, it is important to acknowledge the potential gender wage discrimination operating through lower wages of typically female part-timers in Germany. ${ }^{10}$

The wage data is censored from above (top coded), which affects approximately 10 (4) percent of the wage records in West (East) Germany for both years. Hence, our descriptive analysis focuses on median wage gaps and we also check for sensitivity to top-coding in our regression analysis. On the other hand, the wage information in the IAB data has an important advantage in that the wage definition is the same across all time periods and firms. The social security administration performs various plausibility checks on the wage data and issues sanctions for misreporting, thereby ensuring high accuracy. The use of administrative records minimizes reporting errors for other variables as well.

\footnotetext{
${ }^{8}$ Even though public servants are not included in the IAB data, 10 to 15 percent of social-security employees work in state institutions or non-governmental organizations in health, public administration or education sectors.

${ }^{9}$ We check for the gender differences in hours worked using the German Socio-Economic Panel in Section 4.1. See Fitzenberger and Wunderlich (2002) for a study of the West German gender pay gap, which uses the same data we use and focuses also on part-time workers.

${ }^{10}$ Wolf $(2002)$ shows that hourly wages of West German part-time female workers are lower than wages of women working full time. Since only few male worker are part-timers, this issue is important for overall gender pay differences. In a recent ruling, the German supreme court stated the right for equal hourly payment between part-time and fulltime employment and also made explicit that a company (in this case the German Post AG) used lower payment of its part-time employees as an indirect way of discriminating against its female workers (BVERFG 1. Senat 2. kammer 19.05.1999. 1 BvR 263/98).
} 
The data have another important advantage: Sampling one percent of all social security notifications results in an extensive database. In 1995 the IAB sample includes over 140 thousand end-of-year employment records in West Germany and over 40 thousand such records in East Germany. ${ }^{11}$ The large scale of the data allows us to precisely estimate the gender composition of occupations and to create a matched employer-employee sub-sample. ${ }^{12}$ Having available several workers from the same firm allows us to explore the extent of the gender wage gap within occupations within firms. Of course, given that we work with a random sample of workers, we can only match several workers to their employer for large firms.

The data used for the estimation was selected as follows: We start with all end-of-year employment notifications - a simple cross-section of employment for 1995. From this data we omit records for non-Germans, home and part-time workers, and records with missing wage information as well as those notifications for full-time employment with daily wages below 60 German Marks (DM). ${ }^{13}$ (A similar procedure was applied to obtain the 1992 sample which is used together with the 1995 data in our longitudinal analysis.) The 1995 data descriptive characteristics are presented in the first two columns of the top panel of Table 1. While the average age of full-time employees contributing to the social security (unemployment insurance) system is comparable across the two parts of Germany, the share of female workers is much higher in East Germany. East German employees also have higher educational levels. ${ }^{14}$

Next, we check whether the IAB sample is consistent with other data sources on the German labor market. Most analyses of the German wage structure rely on the German Socio-Economic Panel (GSOEP), a relatively small, but rich longitudinal household survey. In the next two columns

\footnotetext{
${ }^{11}$ The East-West distinction in the IAB data is based on current residence.

${ }^{12}$ We form the matches using the unique establishment number issued by the German Employment Service.

${ }^{13}$ Our goal is to minimize the possibility of including a part-time worker in our final sample. The choice of the $60 \mathrm{DM}$ cutoff is consistent with the general level of (industry-specific) minimum wages in Germany. Omitting very-low-wage and part-time workers is responsible for the loss of 68 thousand records from the original 1995 end-of-year cross-section of over 277 thousand observations. The second-largest omitted group is that of non-Germans (17 thousand). Only 67 records were dropped due to missing wage information.

${ }^{14}$ The Abitur exam administered at the end of secondary education programs is similar to the British General Certificate of Secondary Education (GCSE) and helps students advance into higher education stages.
} 
of Table 1, we therefore compare the basic characteristics of the IAB sample to those of a GSOEP sub-sample selected to mimic the nature of the IAB data. ${ }^{15}$ Comparing the IAB and GSOEP pairs of columns in Table 1 shows that the two sub-samples have a very similar demographic structure.

Finally, we note that the Social Security administration uses a three-digit occupational classification. We have available a total of 274 detailed occupation classes. Inspection of the occupations' size reveals the presence of one outlier: The class of skilled office clerks covers over 12 percent of workers in both East and West Germany and so it forms the largest occupation in the data. ${ }^{16}$ We want to minimize the possibility of meaningful differences in the content of this large occupation and so we interact this occupation with the 15-branch industry indicator (see, e.g., Dolado et al., 2002, for a similar approach).

\section{Analysis}

\subsection{Descriptive Evidence on Segregation and the Wage Gap}

What are the main gender patterns of employment among full-time workers contributing to the social security system in our two economies? First, the share of women is higher in East Germany at 39 percent compared to 33 percent in West Germany in 1995 (Table 1), possibly reflecting the higher male propensity to enter self-employment in the early transition period (see, e.g., Hunt, 2002). Focusing on gender employment patterns across the 274 IAB occupation classes, we find that the relative gender composition of occupational employment is very similar in the two parts of Germany despite the different history (of labor market practices) as the East-West correlation of the share of females at the 3-digit occupation level equals 0.91 .

A summarizing measure of occupational gender segregation typically used in the literature is

\footnotetext{
${ }^{15}$ We start with the basic GSOEP sample and drop self-employed, civil servants as well as part-time and very-lowwage workers. We apply the cross-sectional GSOEP weights to generate the reported sample characteristics.

${ }^{16}$ The second largest occupational class covers less than $4 \%$ of all workers in both East and West Germany; the rest of the size distribution is continuous. The skilled office clerks category, Bürofachkräfte in German, includes secretaries or personal assistants, but not typists (Stenographen, Stenotypisten, Mashienenschreiber, Datentypisten) or support clerical staff (Bürohilfskräfte).
} 
the Duncan and Duncan (1955) segregation index $S$ defined as

$$
S=\frac{1}{2} \sum_{i}\left|m_{i}-f_{i}\right|
$$

where the subscript $i$ denotes occupation, $m_{i}$ is the proportion of males employed in occupation $i$ and $f_{i}$ is the corresponding fraction of females. The index can be interpreted as reflecting the sum of worker reallocation (cross-occupation moves) required to balance the gender composition of all occupations. In 1995, the index takes on the value of 61 percent in West Germany and 65 percent in East Germany, signaling somewhat higher occupational gender segregation there.

What is the size of the gender wage gap for full-time employees contributing to the social security system on the post-unification labor market? We represent the gap using the wage disadvantage of women defined as $1-\overline{w_{f}} / \overline{w_{m}}$, where $\overline{w_{m}}$ stands for the median male wage and $\overline{w_{f}}$ is the corresponding female wage. In 1995, the median unconditional wage gap, expressed in percentage points, is 22 in West Germany but it is -1 in East Germany (see the bottom panel of Table 1). We also estimate the mean gender wage gaps, which are larger at 30 percent in West Germany and 6.2 percent in East Germany. ${ }^{17}$ These are striking findings. The Eastern gap is remarkably low: It is only about one fifth the size of the Western gap using the mean wage comparison. Even more striking is the finding based on median wages: A typical East-German full-time female employee is paid slightly more than her male counterpart.

These results call for comparison. Again, we use the sub-sample of the 1995 GSOEP data mimicking the composition of the IAB data and report the resulting wage gaps in Table $1 .{ }^{18}$ Using

\footnotetext{
${ }^{17}$ The mean is estimated as $E[w]=\operatorname{Pr}\left(w<w^{c}\right) E\left[w \mid w<w^{c}\right]+\operatorname{Pr}\left(w \geq w^{c}\right) w^{c}$, where $w^{c}$ is the top-coded wage value.

${ }^{18}$ The two wage measures are obviously different in many respects. The administrative IAB wage measure includes bonuses and fringe benefits, while these are excluded from the GSOEP wages based on survey responses. Both the IAB and GSOEP wages we use are not corrected for gender differences in hours worked. Information on hours worked is available in GSOEP. Constraining the GSOEP sample to mimic the IAB data (full-time workers, no civil servants or self-employed) and dropping observations with weekly hours below 30 or above 60, gender differences in contractual (actual) hours are in the order of 1 (5) percent in both East and West Germany in both 1992 and 1995. We conclude that (i) the East German wage-rate gap may be even more negative than we report, and (ii) differences in hours worked are unlikely to affect our East-West comparison. Nevertheless, the size of the bias is unclear as Pannenberg (2002) reports that a large fraction of overtime hours is unpaid in West Germany.
} 
the GSOEP self-reported wage measure, we replicate the IAB median wage gap in West Germany and we also confirm that the East German wage gap is very small. The remaining difference of about 4 percentage points in our estimate of the East German median wage gap may be due to sampling error as the East German restricted GSOEP sample consists of only 1425 workers. Further, the mean wage gap in our GSOEP sub-sample is 26 percent in West Germany and 7 percent in East Germany, quite close to our IAB approximate mean wage gaps.

It is natural to ask whether the lack of median wage differences in East Germany corresponds to a fully equalized wage setting in which men and women working on the same job are paid equally. A unique advantage of the IAB data is that it allows one to answer this question directly. Using the matched employer employee sub-sample (see Section 3) we can ask about pay differences between men and women working in the same detailed occupation in the same firm - in the same job. The bottom panel of Table 1 compares the overall wage gaps to those based on within-job comparisons. Each entry is the percentage wage disadvantage for females averaged across all job cells where we could match at least one male and one female worker, that is predominantly in large firms. The results imply that median wages of such male and female co-workers differ by about 7 percent in East Germany and by about 15 percent in West Germany. ${ }^{19}$

These are remarkably large within-job wage gaps, especially in the context of the overall differences in male and female wages, which are, however, based on a broader sample of all workers and firms. In West Germany, there is a wage gap of almost one sixth among workers of different gender on the same job. In part, the job-cell wage gap may be caused by differences in hours worked, but its extent calls for further investigation of potential violations of the equal pay act. The size of the within-job wage gap also suggests that occupational segregation may not be an important source of the relatively large West German overall wage gap. In East Germany, our results thus far suggest

\footnotetext{
${ }^{19}$ The average wage gaps are only slightly higher than the median wage gaps. The averages are taken across all observed job-cell wage-gap observations. Weighting by the size of each observed worker group makes no material difference. The median wage gaps are not sensitive to constraining the analysis to job cells with at least 3 men and 3 women or to further sub-dividing each job cell using broad age groups.
} 
the coexistence of a significant gender wage gap within jobs with an almost fully equalized overall wage. A leading potential explanation for such a pattern of wage gaps is that 'female' occupations pay more. We explore this hypothesis below.

\subsection{Accounting for the Wage Gap}

In this section, we account for the sources of the observed wage gaps using logarithmic wage regressions. Specifically, we ask about the explanatory power of (i) worker and firm characteristics, and (ii) occupational segregation. Following the literature (e.g., Groshen, 1991; Macpherson and Hirsh, 1995; or Bayard et al., 2003), we capture the effect of gender segregation on wages by conditioning on the 'femaleness' of occupations. 'Femaleness' is measured by the percent of females $(P)$ in a given group of employees. We therefore estimate logarithmic Least Squares wage regressions of the following form separately for each gender and part of Germany:

$$
\ln w_{i j}=\mathbf{X}_{i j}^{\prime} \boldsymbol{\beta}+P_{j} \gamma+\eta_{j}+\epsilon_{i j}, \text { with } i=1, \ldots N_{j}, \text { and } j=1, \ldots, J
$$

Here, $w_{i j}$ denotes the daily wage of the $i$-th worker in the $j$-th occupation, $\mathbf{X}_{i j}$ represents the observed worker and firm characteristics, $P_{j}$ is the fraction of female employment in $j$-th occupation, $\eta_{j}$ captures the occupation-specific unobservable attributes, $\epsilon_{i j}$ includes the unobserved workerspecific skills, $J$ denotes the total number of occupations, and $N_{j}$ is the number of workers in the sample employed in the $j$-th occupation. ${ }^{20}$

Equation 1 highlights two important sources of estimation problems. Unfortunately, we are not able to fully control for the first unobservable, the occupation-specific attributes $\eta_{j}$, which may lead to an upward bias in $\gamma$ if women prefer occupations which offer costly attributes (e.g., flexible working hours or lack of physical-strength demands). Secondly, sorting of workers into occupations based on unobservable skills is a feature of an important hypothesis in the occupational segregation literature (see Section 2.1). If the occupational averages of worker unobserved skills $\left(\epsilon_{i j}\right)$

\footnotetext{
${ }^{20}$ Our statistical inference acknowledges the likely correlation of unobservables within occupations and allows for occupation-level clustering.
} 
are correlated with the 'femaleness' of occupations $\left(P_{j}\right)$, this would again lead to a biased estimate of $\gamma$. One can remove the time-constant unobservable worker skills by "differencing" observations for the same worker from two time periods. We follow this strategy below, but first, we focus on traditional cross-sectional estimates.

\subsubsection{Basic Explanations}

Here, we estimate least-squares log-wage regressions for West and East Germany controlling for both worker and firm characteristics, but not for occupational segregation measures. Given the absence of actual labor market experience in the data, we choose to include among the regressors the number of children and a marriage indicator together with a quadratic in age. We also control for a set of educational attainment indicators and condition on the type of employer by including a set of industry and firm-size dummies.

Next, we use the estimated coefficients to ask about the sources of the gender wage gaps in Germany using the Oaxaca-Blinder decomposition. A general form of the mean wage decomposition is as follows:

$$
\overline{\ln w_{m}}-\overline{\ln w_{f}}=\left(\overline{\mathbf{X}_{m}}-\overline{\mathbf{X}_{f}}\right)^{\prime} \widetilde{\boldsymbol{\beta}}+\left[{\overline{\mathbf{X}_{m}}}^{\prime}\left(\widehat{\boldsymbol{\beta}_{m}}-\widetilde{\boldsymbol{\beta}}\right)+{\overline{\mathbf{X}_{f}}}^{\prime}\left(\widetilde{\boldsymbol{\beta}}-\widehat{\boldsymbol{\beta}_{f}}\right)\right]
$$

where $f$ denotes females and $m$ denotes males, $\overline{\ln w_{s}}$ is the gender-specific mean of the natural logarithm of hourly wage, $\overline{\mathbf{X}_{s}}$ represents the respective vectors of mean values of explanatory variables for men and women with $s \in\{f, m\}$. Finally, $\widehat{\boldsymbol{\beta}_{m}}$ and $\widehat{\boldsymbol{\beta}_{f}}$ are the corresponding vectors of estimated coefficients from gender-specific wage regressions and $\widetilde{\boldsymbol{\beta}}$ represents a counter-factual non-discriminatory wage structure. The first term on the right hand side of equation 2 represents that part of the total logarithmic wage difference which stems from the difference in average observed productive characteristics across gender. The second term originates in the differences in gender-specific coefficients from the non-discriminatory wage structure and is often interpreted as providing an upper limit on potential wage discrimination. There are a number of variants of this method depending on how one approximates the non-discriminatory wage structure; see Oaxaca 
and Ransom (1994). In line with their recommendation, we use the weighted average of the genderspecific coefficients with weights corresponding to shares of each gender out of all employment (for a similar approach, see, e.g., Macpherson and Hirsh, 1995).

The basic decomposition results are presented in Table $2 .{ }^{21}$ Summing up the products of average coefficients (column 1 or 3 ) and $X$ differences (column 2 or 4 ) for each part of Germany, we find that gender differences in demographic and firm characteristics account for 7.5 percentage points of the overall gender wage gap in West Germany. In East Germany, however, we find that the gender differences in productive characteristics actually work to women's advantage, reducing the gap which would have been larger if the distribution of $X$ was equalized across men and women. (For qualitatively similar findings from post-communist countries, see Ogloblin, 1999, or Jurajda, 2003.) In particular, we note that East German women have better educational levels than their male colleagues and that they are more likely to work in the highly-paid service and public-administration sectors.

\subsubsection{Cross-Sectional Effects of Occupational Segregation}

Our main goal is to learn about the importance of occupational segregation for wages. Next, we therefore introduce a new regressor, namely the share of female workers in occupation. A set of these coefficients of interest from different specifications is presented in Table 3 .

Column (1) shows the coefficients of female occupational segregation from regressions including no other controls. While the West German correlations are not statistically significant, the East German estimates are positive and very large. One possible explanation is that workers in highly 'female' occupations have higher (observable) productive characteristics. In column (2), occupational segregation is therefore controlled for in the preferred specification with all firm and worker controls from Table 2. ${ }^{22}$ The West German occupational segregation coefficients we obtain still

\footnotetext{
${ }^{21}$ The gender-specific sets of estimates are available in Jurajda and Harmgart (2004); they suggest very similar returns to education across both economies and genders as well as a strong similarity in the estimated industry wage structures.

${ }^{22}$ The unreported demographic and firm coefficients remain stable after the introduction of the gender segregation
} 
imply no statistically significant relationship between the 'femaleness' of 3-digit occupations and wages of either men or women. This is in contrast to the stylized facts of the U.S. literature (see, e.g., Macpherson and Hirsh, 1995) which finds negative effects of female occupational concentration on wages of both genders. Even more striking are the East German estimates: The coefficients on the fraction of females in occupation are both still positive and statistically significant. ${ }^{23}$ This flies in the face of both the U.S. evidence and the available work from transition countries.

In the remaining columns of Table 3 , we assess the sensitivity of our main estimates to alternative specifications and estimation techniques. Baker and Fortin (2001) argue that, because of human capital externalities, one should also control for average characteristics of co-workers in an occupation. In column (3) we therefore ask whether higher educational level of workers in the same occupation (but typically a different firm) increases a worker's wage independent of the owneducation effect. Specifically, we introduce three additional regressors consisting of the fraction of an occupation's workforce with a (i) college degree, (ii) Abitur exam, and (iii) apprenticeship degree. The (unreported) regression coefficients corresponding to these additional controls are always positive and statistically significant. However, their introduction leads to no qualitative change in the parameters of interest: The East German segregation coefficients are smaller, but remain positive and statistically significant, while the West German coefficients are still insignificant.

In column (4) we check the sensitivity of the OLS estimates to the top coding of IAB wages, which in principle renders OLS inconsistent. So far, we have ignored the issue of right censoring of wages and included the observations with top-coded wages in the OLS estimation. Now, we compare the OLS results to those based on the Censored Least Absolute Deviation (CLAD) estimator proposed by Powell (1984).${ }^{24}$ Column (4) of Table 3 lists the gender segregation coefficients from the CLAD regressions together with bootstrapped standard errors. Comparing the new estimates to the Least-

${ }^{24}$ CLAD is based on the assumption of zero median of the model error distribution. It is not a least-squares but a median (quantile) regression and, unlike parametric censored-regression models (i.e., Tobit), it permits non-normal, heteroscedastic, and asymmetric errors.
} 
Squares parameters from column (2) shows little material difference. Furthermore, the workerand firm-specific coefficients are also little affected. ${ }^{25}$ We therefore conclude that ignoring right censoring has a negligible quantitative effect on our parameters, which justifies the mean wage-gap decompositions based on the OLS estimates.

Up to now, we have estimated worker-level regressions, but our parameters of interest were identified using group-level (occupation-level) variation. Hence, we adjusted standard errors by clustering residuals at the occupation level. There is an alternative way of reflecting the different degrees of freedom involved in estimating the worker-specific and occupation-specific coefficients: One may first estimate a regression with individual-specific regressors and occupational fixed effects and in a second stage regress the estimated occupational dummies on the share of females in occupation, weighting by the occupation's size. ${ }^{26}$ Our estimated parameters from these secondstage regressions are in full accord with those based on worker-level analysis. Again, both West German coefficients are small (0.03 for men and -0.04 for women) and statistically insignificant, while the East German coefficients are both positive and highly statistically significant (0.08 for both men and women). We note that weighting by occupation's size is important; giving each occupation equal weight would result in a negative effect for West German men.

\subsubsection{Person-Fixed-Effect Specifications}

Our estimates up to now have been based on cross-sectional variation in occupation-specific female concentration. How can we interpret our findings thus far? In particular, why do 'female' occupations pay more in East Germany? In searching for an answer we turn to the specific labor market history and institutions in East Germany. The transition from communism in East Germany led to a dramatic fall in female employment rates while wage levels rapidly rose to near-western levels. This suggests a marked tendency towards selection of East German women into employment based

\footnotetext{
${ }^{25}$ These results are available in Jurajda and Harmgart (2004).

${ }^{26}$ See Baker and Fortin (2001) for a discussion of the ramifications of the one-step and two-step estimators for potential biases from occupation-level omitted variables.
} 
on labor quality. We know that during early pro-market reforms in East Germany low-wage women were more likely to become jobless while East German men were more likely than women to enter self-employment (become entrepreneurs) and therefore disappear from our data (Hunt, 2002). If entry into self-employment is highly correlated with observed and unobserved skills, the East German men remaining in social-security-covered employment may be of relatively low skill quality. On the other hand, if low-skill women are not employed, the pool of social-security-covered female employees may be of relatively high quality.

Indeed, our Oaxaca-Blinder decomposition in Table 2 suggests that, unlike in West Germany, the observed labor quality of female employees in East Germany is higher than that of their male colleagues. If, as one would expect, there is a positive correlation between observable and unobservable skills of workers (Gibbons and Katz, 1992), East German women may also have better unobservables. A positive correlation between the share of women in an occupation and the occupation-specific unobserved labor quality would then lead to the surprising positive coefficient on occupational 'femaleness' for females. Furthermore, if the share of women in an occupation becomes an index of labor quality, then high-skill men may sort themselves into such occupations (Kremer, 1993), giving rise to a positive effect of occupations' 'femaleness' for males. If the percentage of females in an occupation serves as a proxy for skill level, then the 'femaleness' coefficients should decline with the introduction into a regression of productivity controls. Comparing columns (1) and (2) of Table 3, we see that this is indeed the case. ${ }^{27}$

Here, we shed more light on the quality sorting hypothesis using the panel dimension of our data. Following Macpherson and Hirsh (1995), we condition on person-specific unobservables, including skills, by estimating worker-fixed-effect regressions. These "within" regressions use a subsample

\footnotetext{
${ }^{27}$ One could alternatively explain the positive effect of occupational 'femaleness' on male wages as corresponding to a compensating wage differential for men who would prefer to work with other men, but accept positions in occupations predominantly staffed with women. This explanation is attractive because we know that in Germany wages can differ according to gender within narrowly defined worker groups (Table 1). However, this hypothesis is less useful in explaining why wages of women working in predominantly 'female' occupations are higher compared to those of women working in 'male' occupations.
} 
of workers employed in both 1992 and 1995 consisting of 30 and 114 thousand employees in East and West Germany respectively. ${ }^{28}$ It is important to discuss the sources of variation in "withinperson" occupation characteristics, such as the share of women. Over time, the 'femaleness' of one's occupation can change both for workers who remain in the same occupation and for those who switch occupations between 1992 and $1995 .{ }^{29}$ To the extent that they are exogenous to discriminatory gender segregation, occupation moves provide an important source of identification for the 'true' segregation effect. ${ }^{30}$ The IAB panel we use is rich in that it covers 16 (8) thousand of such occupation moves in West (East) Germany. ${ }^{31}$

Table 4 presents the results based on the 1992-95 panel subsample. First, we check whether the cross-sectional estimates of the 'penalty' to 'female' occupations from column (2) of Table 3 are replicated in the panel subsample. We obtain qualitatively equivalent parameters in column (1) of Table 4 in that the West German occupational 'femaleness' coefficients remain small and are not statistically significant. The East German male coefficient is also in accord with the cross-sectional estimate based on all 1995 workers, but the female parameter is now close to zero. In column (2) of Table 4 we re-estimate the cross-sectional relationship using the smaller group of occupation movers who provide the strongest source of identification for the "within-person" estimation. Here, we are able to closely replicate both of the East German occupational coefficients as well as the male West German estimate, but the female West German parameter estimate grows and becomes statistically significant (but remains within one standard error of the preferred cross-sectional estimate). Overall,

\footnotetext{
${ }^{28}$ The (unreported) cross-sectional parameters from 1992 are very similar to those presented in Table 3 for 1995. Hence, the assumption of constant coefficients across the two years, embedded in the fixed-effect model, is reasonable. At the same time, the 3 year gap is long enough to allow for changes in wages resulting from changes in occupations to take place.

${ }^{29}$ The occupation-level time changes of 'femaleness' separate from those coming from the observed (sample of) occupation moves come from the occupation-gender structure of employment inflow and outflow, which is not captured in the panel sub-sample.

${ }^{30}$ Using fixed-effect regressions and assuming exogeneity of occupation moves to control for unobserved personspecific characteristics is an alternative to estimating joint models of wage determination and (female) employment participation and occupation choice. The estimation (and identification) of such models goes beyond the scope of the recent literature on gender segregation. In our case, we refer the reader to Hunt (2002) for evidence on the role of labor quality for employment participation in East Germany.

${ }^{31}$ In both parts of Germany, about 70\% of the occupation movers also changes firms between 1992 and 1995.
} 
we conclude that the most important feature of our cross-sectional analysis, namely the positive 'bonus' to 'female' occupations in East Germany is preserved in the panel subsamples.

Finally, columns (3) and (4) of Table 4 present the estimates of the effect of an occupation's 'femaleness' on wages based on "within-worker" time-change variation. ${ }^{32}$ These results are not affected by time-constant differences in worker unobservables (skills and preferences) and may therefore come closer to a causal effect of segregation on wages. Using this different source of variation, we obtain a dramatically different set of coefficients. Conditioning on both observed and unobserved personal characteristics results in negative effects of occupational segregation in West Germany and zero effects in East Germany, completely eliminating its positive cross-sectional occupational segregation coefficients. This is consistent with our hypothesis of the positive effects being driven by sorting on unobserved skill differences. ${ }^{33}$

Using the notation of equation 1 we are now ready to calculate the contribution of gender segregation to overall wage gaps as $\left(\overline{P_{m}}-\overline{P_{f}}\right)\left[\varphi \widehat{\gamma_{m}}+(1-\varphi) \widehat{\gamma_{f}}\right]$, where $\varphi$ is the share of males in the group of full-time workers contributing to the social security system, $\widehat{\gamma}_{s}$ are the estimated gender-specific segregation coefficients, and where $\overline{P_{s}}$ contains the averages of the female-share regressor for each gender.

We perform this calculation twice, in both cases using the cross-sectional mean differences in $P$ from 1995. First, we use the cross-sectional parameter estimates from column (2) of Table 3. The calculation suggests that in West Germany gender segregation does not explain any part of the overall wage gap, while in East Germany it makes female wages 5.5 percentage points higher than male wages. Second, we use the panel-data coefficients based on occupational movers (column (4) of Table 4). Here, we find that in West Germany gender segregation explains 2 percentage points of the overall wage gap, but it gives rise to no gender-related wage differences in the east part of

\footnotetext{
${ }^{32}$ The clustering of unobservables used to correct standard errors now occurs by occupation pairs across the two years.

${ }^{33}$ On the other hand, this finding is not consistent with the alternative explanation for the male positive 'femaleness' effect based on a compensating wage differential for men who prefer to work with men, but accept working with women.
} 
Germany. Overall, we believe that our panel-data results point to (i) high unobserved quality of East German female employees leading to a positive sorting on skills across occupations, and (ii) a small causal contribution of gender segregation toward explaining the overall wage gaps in both parts of Germany.

\section{Conclusions}

This paper provides evidence on the size of the gender wage gap, the extent of occupational gender segregation, and on the effects segregation has on the gender pay differences in East and West Germany in 1995. The analysis is based on full-time employees only and does not cover civil servants and the self-employed.

Our analysis uncovers intriguing East-West differences. Women form a larger share of full-time employment in East Germany, but the relative gender structure of occupational employment is similar in East and West Germany, despite the different history. Strikingly, there are no median wage differences between workers of different genders in East Germany. Our East German data also imply a very small unconditional mean daily wage gap in the order of one fifth of the West German gap. In contrast, the mean (median) wage gap in West Germany is substantial at 30 (22) percent. Despite the difference in the overall wage gaps, we uncover significant wage gaps within jobs (occupation-firm cells) in both parts of Germany.

Our regression analysis reconciles these pieces of descriptive evidence: Using cross-sectional wage variation, we find little support for the existence of a wage 'penalty' to 'female' jobs in West Germany. Occupational segregation therefore does not explain the greater wage gap in West Germany. The significant within-job wage gaps in East Germany do not appear at the aggregate level because more 'female' occupations actually offer higher wages, in striking contrast to findings from the U.S. as well as from transition countries.

We suggest a possible interpretation for this finding based on the unique nature of transition 
from central planning in East Germany. German unification brought about the imposition of nearwestern wage levels against a background of mass layoffs. We know that this resulted in a strong selection of women into employment based on labor quality (Hunt, 2002). Indeed, productive characteristics of our East German female employees are higher than those of their male colleagues. If the share of women in an occupation becomes a measure of skill quality, high productivity men may sort themselves into predominantly 'female' occupations.

One check of this hypothesis is to control for unobservable worker heterogeneity (skills) using the longitudinal portion of the data. Following the existing literature, we assume that workers switch occupations for reasons unrelated to discrimination, and use the resulting "within-worker" time variation in 'femaleness' of occupations to estimate worker-fixed-effect regressions. Conditioning on unobservable time-constant worker characteristics, we find no evidence of an effect of occupational segregation on East German wages. This is consistent with the quality sorting hypothesis, but not with other explanations for the East German 'bonus' to 'female' jobs. In West Germany, we find a small negative wage effect of segregation based on within-worker variation.

Our analysis has implications for both gender public policy and the existing literature on occupational gender segregation. First, we suggest that discriminatory crowding of women into low-wage occupations is not important in Germany, including its east states where anti-discriminatory laws were introduced only recently. However, we find the scope for potential violations of the equal pay clauses to be significant in both parts of Germany. In West Germany, occupational gender segregation combines with an uneven distribution of (observed) productive characteristics to account for up to 10 percentage points of the overall 30-percent difference between the mean wages of men and women, which leaves two thirds of the gap unexplained. In East Germany, the low overall wage gap is in part due to the distribution of productive characteristics of full-time employees favorable to women.

Second, our evidence implies that the typical negative cross-sectional relationship between 'fe- 
maleness' of occupations and wages of both men and women, present in U.S. as well as CentralEuropean research (Bayard et al., 2003; Jurajda, 2003), does not stand in a country with very low female employment and high wage floors. Female full-time employment rates are much lower in Germany than in the U.S. or Central Europe, but these differences are smaller for men (OECD, 2002; Beaudry and Green, 2003). Wage floors are lower in the U.S. than in West Germany and they rose only slowly in most transition economies in comparison to East Germany. Our findings are consistent with the notion that if mainly highly productive women are employed (due to, e.g., high wage floors), this may eliminate the typical negative correlation between the share of females in occupation and wage level in that occupation. This hypothesis is also supported by OECD (2002) — a cross-country study based largely on the European Community Household Panel — which suggests that cross-country differences in female employment rates are driven mainly by the degree of integration of less-educated, lower-paid women into employment and that such compositional effects are important for understanding international differences in the gender pay gap as well as in the extent of segregation.

Does our hypothesis also offer an explanation for the East-West differences in the cross-sectional wage effects of occupational segregation? While female employment rates are similar in both parts of Germany, wage floors may be more "effective" in preventing employment of the less productive female workers in East Germany, given the lower level of overall productivity there. Focusing on observable characteristics, full-time East German female employees have higher skills than their male colleagues while the opposite is true for West Germany. If the selection of women into fulltime employment is also more strongly affected by unobservable skill quality in East Germany than in the west states, this could offer an explanation for the difference in our estimated wage 'penalty' to 'female' occupations in East and West Germany.

We believe that these tantalizing comparisons motivate future cross-country research linking the size of the wage 'penalty' to 'female' occupations with wage floors and skill structure of female 
employment. Such research would be complementary to the within-country longitudinal studies, which control for unobservable worker skills by relying on the potentially questionable exogeneity of worker occupation moves.

\section{Bibliography}

Baker, Michael, Fortin, Nicole M., 1999. Women's Wages in Women's Work: A U.S./Canada Comparison of the Roles of Unions and "Public Goods" Sector Jobs. American Economic Review 89 (2), 198-203.

Baker, Michael, Fortin, Nicole M., 2001. Occupational Gender Composition and Wages in Canada, 1987-1988. Canadian Journal of Economics 34 (2), 345-376.

Bayard, Kimberly, Hellerstein, Judith K., Neumark, David, Troske, Kenneth R., 2003. New Evidence on gender Segregation and gender Differences in Wages from Matched EmployeeEmployer Data. Journal of Labor Economics 21(4), 887-922.

Beaudry, Paul, Green, David A., 2003. Wages and Employment in the United States and Germany: What Explains the Difference? American Economic Review 93 (3), 573-602.

Bender, Stefan, Haas, Anette, Klose, Christoph, 2000. IAB Employment Subsample 1975-1995 Opportunities for Analysis Provided by the Anonymised Subsample. IZA Discussion Paper No. 117.

Bertola, Giuseppe, Blau, Francine D,. Kahn, Lawrence M., 2002. Labor Market Institutions and Demographic Employment Patterns. CEPR Discussion Paper No. 3448.

Blau, Francine D,. Kahn, Lawrence M., 2003. Understanding international differences in the gender pay gap. Journal of Labor Economics 21 (1), 106-144.

Bonin, Holger, Euwals, Rob, 2002. Participation Behavior of East German Women After German Unification. CEPR Discussion Paper No. 3201.

Brainerd, Elizabeth, 1998. Winners and Losers in Transition. American Economic Review 88(5), 1094-1116. 
Brainerd, Elizabeth, 2000. Women in Transition: Changes in Gender Wage Differentials in Eastern Europe and the Former Soviet Union. Industrial and Labor Relations Review 54(1), 138-162.

Burda, Michael C., Hunt, Jennifer, 2001. From Reunification to Economic Integration: Productivity and Labor Markets in Germany. Brookings Papers on Economic Activity 2, 1-71.

Dolado, Juan J., Felgueroso, Florentino, Jimeno, Juan F., 2002. Recent Trends in Occupational Segregation by Gender: A Look Across the Atlantic. IZA Discussion Paper No. 524.

Duncan, Otis Dudley, Duncan, Beverly, 1955. A Methodological Analysis of Segregation Indexes. American Sociological Review 20, 210-217.

Filer, Randal K., 1986. The Role of Personality and Tastes in Determining Occupational Structure. Industrial and Labor Relations Review 39 (3), 412-424.

Fitzenberger, Bernd, Wunderlich, Gaby, 2002. Gender Wage Differences in West Germany: A Cohort Analysis. German Economic Review 3 (4), 379-414.

Gang, Ira N., Yun, Myeong-Su, 2001. The Gender Wage Gap and Discrimination, East Germany 1990-1997. DIW-Vierteljahrshefte (Quarterly Journal of Economic Research) 1-01, 123-127.

Gibbons, Robert, Katz, Lawrence F. , 1992. Does Unmeasured Ability Explain Inter-industry Wage Differentials? Review of Economic Studies 59(3), 515-35.

Groshen, Erica L., 1991. The Structure of the Female/Male Wage Differential: Is it Who You Are, What You Do, or Where You Work? Journal of Human Resources 26 (3), 457-72.

Hunt, Jennifer, 2002. The Transition in East Germany: When is a Ten Per Cent Fall in the Gender Pay Gap Bad News. Journal of Labor Economics 20 (1), 148-169.

Jolliffe, Dean, 2002. The Gender Wage Gap in Bulgaria: A Semiparametric Estimation of Discrimination. Journal of Comparative Economics 30 (2), 276-295.

Jurajda, Štěpán, 2003. Gender Wage Gap and Segregation in Enterprises and the Public Sector in Late Transition Countries. Journal of Comparative Economics 31 (2), 199-222. 
Jurajda, Štěpán, Harmgart, Heike, 2004. When Do 'Female' Occupations Pay More? CEPR Discussion Paper No. 4270.

Killingsworth, Mark R., 1990. The Economics of Comparable Worth. Kalamazoo, Michigan: W. E. Upjohn Institute for Employment Research.

Kremer, Michael, 1993. The O-ring theory of Economic Development. Quarterly Journal of Economics 108 (3), 551-575.

Kunze, Astrid, 2003. Gender Differences in Entry Wages and Early Career Wages. Annales d'Economie et Statistique 71/72, 245-266.

Macpherson, David, Hirsh, Barry T., 1995. Wages and Gender Composition: Why Do Women's Jobs Pay Less. Journal of Labor Economics 13, 426-471.

Newell, Andrew, Reilly, Barry, 2000. The Gender Wage Gap in the Transition from Communism: Some Empirical Evidence. William Davidson Institute Working Paper No. 305.

Oaxaca, Ronald R., Ransom, Michael R., 1994. On Discrimination and the Decomposition of Wage Differentials. Journal of Econometrics 61, 5-21.

OECD, 2002. OECD Employment Outlook 2002 Women at Work: Who Are They and How are They Faring. OECD, Paris.

Ogloblin, Constantin G., 1999, The Gender Earnings Differential in the Russian Transition Economy. Industrial and Labor Relations Review 52(4), 602-27.

Pannenberg, Markus, 2002. Long-Term Effects of Unpaid Overtime: Evidence for West Germany. IZA Discussion Paper No. 614.

Powel, James L., 1984. Least Absolute Deviation Estimation for the Censored Regression Model. Journal of Econometrics 25 (3), 303-25.

Wolf, Elke, 2002. Lower Wage Rates for Fewer Hours? A Simultaneous Wage-Hours Model for Germany. Labour Economics 9, 643-663. 
Table 1: Descriptive Statistics of the IAB and GSOEP 1995 Worker Samples ${ }^{\text {a }}$

\begin{tabular}{|c|c|c|c|c|}
\hline & \multicolumn{2}{|c|}{$\mathrm{IAB}^{\mathrm{b}}$} & \multicolumn{2}{|c|}{ GSOEP $^{\mathrm{C}}$} \\
\hline & West & East & West & East \\
\hline \multicolumn{5}{|c|}{ Demographic Composision } \\
\hline Mean age & 39.1 & 39.6 & 39.4 & 40.4 \\
\hline Female (\%) & 33.1 & 38.9 & 33.2 & 40.1 \\
\hline \multicolumn{5}{|l|}{ Education (\%) } \\
\hline No apprenticeship, no abitur & 13.4 & 4.4 & 13.5 & 4.0 \\
\hline Apprenticeship, no abitur & 72.5 & 78.9 & 69.7 & 78.3 \\
\hline Abitur & 4.7 & 3.4 & 5.4 & 6.0 \\
\hline College or university & 9.4 & 13.3 & 11.5 & 11.7 \\
\hline Firm size $<20$ workers (\%) & 23.2 & 24.9 & 19.3 & 26.2 \\
\hline No. of workers & 141222 & 40094 & 2034 & 1425 \\
\hline No. of firms & 84307 & 25349 & -- & -- \\
\hline \multicolumn{5}{|c|}{ Gender Wage Gaps } \\
\hline Median gender wage gap ${ }^{d}$ & 21.8 & -0.9 & 22.2 & 3.2 \\
\hline Median gap within job cells ${ }^{\mathrm{e}}$ & 14.5 & 6.7 & -- & -- \\
\hline No. of job cells & 5044 & 1349 & -- & -- \\
\hline Avg. no. of workers per firm in data & 10.5 & 4.8 & -- & -- \\
\hline
\end{tabular}

${ }^{\mathrm{a}}$ Observations for full-time workers with gross daily wage above 60DM; no civil servants, self-employed, home workers, or trainees, and no non-Germans.

bample based on a cross-section of end-of-year social-security notifications.

'Sub-sample mimicking the IAB data (a); person-specific cross-sectional weights are used.

${ }^{\mathrm{d}}$ Female Wage Disadvantage as \% of Male Wage $\left(1-\mathrm{w}_{\mathrm{f}} / \mathrm{w}_{\mathrm{m}}\right)$

${ }^{\mathrm{e}} \mathrm{A}$ job cell consists of workers in the same firm with the same occupation. 
Table 2: Mean Gender Wage Gap Contribution of Worker and Firm Characteristics in 1995

\begin{tabular}{|c|c|c|c|c|c|c|}
\hline & $\begin{array}{c}\text { Average } \\
\text { Coefficient } \\
(1) \\
\end{array}$ & $\begin{array}{c}\text { Difference } \\
\text { in Mean X } \\
(2)\end{array}$ & $\begin{array}{c}\text { Absolute } \\
\text { Contribution } \\
(1)^{*}(2) \\
\end{array}$ & $\begin{array}{c}\text { Average } \\
\text { Coefficient } \\
(3) \\
\end{array}$ & $\begin{array}{c}\text { Difference } \\
\text { in Mean X } \\
(4)\end{array}$ & $\begin{array}{c}\text { Absolute } \\
\text { Contribution } \\
(3) *(4) \\
\end{array}$ \\
\hline & \multicolumn{3}{|c|}{ West Germany } & \multicolumn{3}{|c|}{ East Germany } \\
\hline Married & 0.032 & 0.177 & 0.006 & 0.038 & -0.045 & -0.002 \\
\hline Number of Children & -0.014 & 0.052 & -0.001 & -0.008 & 0.069 & -0.001 \\
\hline Age & 0.037 & 3.205 & 0.117 & 0.022 & -0.158 & -0.004 \\
\hline Age*Age/100 & -0.037 & 2.405 & -0.089 & -0.024 & -0.055 & 0.001 \\
\hline Apprenticeship, No GCSE & 0.179 & -0.002 & 0.000 & 0.114 & 0.003 & 0.000 \\
\hline Secondary Educ. with GCSE & 0.299 & -0.025 & -0.007 & 0.293 & -0.017 & -0.005 \\
\hline University and more & 0.459 & 0.050 & 0.023 & 0.451 & -0.010 & -0.005 \\
\hline Chemical \& Metal & 0.153 & 0.043 & 0.007 & 0.141 & 0.060 & 0.008 \\
\hline Textile \& Household Goods & 0.046 & -0.016 & -0.001 & 0.067 & -0.009 & -0.001 \\
\hline Mining \& Quarrying & 0.165 & 0.052 & 0.009 & 0.161 & 0.033 & 0.005 \\
\hline Manufacturing & 0.165 & 0.108 & 0.018 & 0.191 & 0.054 & 0.010 \\
\hline Utilities & 0.251 & 0.020 & 0.005 & 0.362 & 0.013 & 0.005 \\
\hline Construction & 0.160 & 0.083 & 0.013 & 0.220 & 0.205 & 0.045 \\
\hline Trade & 0.121 & -0.048 & -0.006 & 0.181 & 0.005 & 0.001 \\
\hline Transport & 0.122 & 0.029 & 0.004 & 0.265 & 0.033 & 0.009 \\
\hline Banks \& Insurance & 0.307 & -0.025 & -0.008 & 0.451 & -0.030 & -0.014 \\
\hline Business Services & 0.240 & -0.002 & 0.000 & 0.338 & -0.005 & -0.002 \\
\hline Public Administration & 0.104 & -0.042 & -0.004 & 0.255 & -0.180 & -0.046 \\
\hline Education & 0.128 & -0.026 & -0.003 & 0.288 & -0.045 & -0.013 \\
\hline Health & 0.105 & -0.100 & -0.011 & 0.273 & -0.092 & -0.025 \\
\hline Other Services & 0.073 & -0.080 & -0.006 & 0.182 & -0.055 & -0.010 \\
\hline Firm employment: 50-99 & 0.087 & 0.005 & 0.000 & 0.061 & 0.028 & 0.002 \\
\hline $100-499$ & 0.125 & 0.003 & 0.000 & 0.093 & -0.034 & -0.003 \\
\hline over 500 & 0.185 & 0.055 & 0.010 & 0.158 & -0.104 & -0.017 \\
\hline Total contribution & & & 0.075 & & & -0.058 \\
\hline
\end{tabular}

Note: Columns (1) and (3) give the female-employment-share weighted average of gender-specific regression coefficients. Columns (2) and (4) give the difference between the male and the female mean of observed characteristics. 
Table 3: Occupational Gender Composition Coefficients from Cross-Sectional Specifications

\begin{tabular}{|c|c|c|c|c|c|c|c|c|}
\hline & $\begin{array}{l}\text { coeff. } \\
(1)\end{array}$ & std.error & $\begin{array}{l}\text { coeff. } \\
(2)\end{array}$ & std.error & $\begin{array}{l}\text { coeff. } \\
(3)\end{array}$ & std.error & $\begin{array}{c}\text { coeff. } \\
(4)\end{array}$ & std.error \\
\hline & \multicolumn{8}{|c|}{ West Germany } \\
\hline Men & 0.057 & $(0.065)$ & 0.037 & $(0.034)$ & -0.027 & $(0.026)$ & 0.043 & $(0.005)$ \\
\hline \multirow[t]{2}{*}{ Women } & -0.138 & $(0.105)$ & -0.054 & $(0.07)$ & -0.002 & $(0.052)$ & -0.049 & $(0.009)$ \\
\hline & \multicolumn{8}{|c|}{ East Germany } \\
\hline Men & 0.295 & $(0.063)$ & 0.124 & $(0.034)$ & 0.057 & $(0.029)$ & 0.097 & $(0.012)$ \\
\hline Women & 0.138 & $(0.085)$ & 0.095 & $(0.056)$ & 0.065 & $(0.039)$ & 0.109 & $(0.011)$ \\
\hline Estimator & \multirow{2}{*}{\multicolumn{2}{|c|}{$\begin{array}{l}\text { Least Squares } \\
\text { all workers }\end{array}$}} & \multirow{2}{*}{\multicolumn{2}{|c|}{$\begin{array}{c}\text { Least Squares } \\
\text { all workers }\end{array}$}} & \multirow{2}{*}{\multicolumn{2}{|c|}{$\begin{array}{c}\text { Least Squares } \\
\text { all workers }\end{array}$}} & \multirow{2}{*}{\multicolumn{2}{|c|}{$\begin{array}{c}\text { CLAD } \\
\text { all workers }\end{array}$}} \\
\hline Sample & & & & & & & & \\
\hline Standard controls & \multicolumn{2}{|c|}{ No } & \multicolumn{2}{|c|}{ Yes } & \multicolumn{2}{|c|}{ Yes+Avg Educ. in Occ. } & \multicolumn{2}{|c|}{ Yes } \\
\hline
\end{tabular}

Note: For a list of standard controls see Table 2. Least-Squares standard errors allow for occupational clustering of unobservables.

Table 4: Occupational Gender Composition Coefficients from the 1992-1995 Panel Sub-Sample

\begin{tabular}{|c|c|c|c|c|c|c|c|c|}
\hline & $\begin{array}{l}\text { coeff. } \\
\text { (1) }\end{array}$ & std.error & $\begin{array}{l}\text { coeff. } \\
(2)\end{array}$ & std.error & $\begin{array}{l}\text { coeff. } \\
(3)\end{array}$ & std.error & $\begin{array}{l}\text { coeff. } \\
(4)\end{array}$ & std.error \\
\hline & \multicolumn{8}{|c|}{ West Germany } \\
\hline Men & 0.057 & $(0.036)$ & 0.070 & $(0.045)$ & -0.034 & $(0.014)$ & -0.035 & $(0.014)$ \\
\hline \multirow[t]{2}{*}{ Women } & -0.050 & $(0.073)$ & -0.128 & $(0.073)$ & -0.091 & $(0.023)$ & -0.078 & $(0.022)$ \\
\hline & \multicolumn{8}{|c|}{ East Germany } \\
\hline Men & 0.152 & $(0.032)$ & 0.164 & $(0.037)$ & -0.014 & $(0.031)$ & 0.008 & $(0.025)$ \\
\hline Women & 0.020 & $(0.047)$ & 0.111 & $(0.054)$ & -0.024 & $(0.053)$ & 0.029 & $(0.038)$ \\
\hline $\begin{array}{l}\text { Estimator } \\
\text { Sample }\end{array}$ & \multicolumn{2}{|c|}{$\begin{array}{l}\text { Least Squares } \\
\text { all workers }\end{array}$} & \multicolumn{2}{|c|}{$\begin{array}{c}\text { Least Squares } \\
\text { occupation movers }\end{array}$} & \multicolumn{2}{|c|}{$\begin{array}{c}\text { Person Fixed Effect } \\
\text { all workers }\end{array}$} & \multicolumn{2}{|c|}{$\begin{array}{l}\text { Person Fixed Effect } \\
\text { occupation movers }\end{array}$} \\
\hline Standard controls & \multicolumn{2}{|c|}{ Yes } & \multicolumn{2}{|c|}{ Yes } & \multicolumn{2}{|c|}{ Yes } & \multicolumn{2}{|c|}{ Yes } \\
\hline
\end{tabular}

Note: For a list of standard controls see Table 2. The panel subsample is based on workers employed in both 1992 and 1995. Standard errors allow for occupational clustering of unboservables; in columns (3) and (4) the clusters correspond to pairs of occupations across the two years. 